\title{
PENINGKATAN ESQ (EMOTIONAL-SPIRITUAL QUOTIENT) MELALUI TAREKAT QODIRIYAH WA NAQSABANDIYAH DI PONDOK PESANTREN MIFTAHUL HUDA MALANG
}

\author{
Improving ESQ (Emotional - Spiritual Quotient) Through Tarekat Qadiriyya WA \\ Naqsabandiyah at Miftahul Huda Islamic School Malang
}

\author{
Mohamad Yasin Yusuf \\ Mahasiswa Program Doktor (S3), Jurusan Kependidikan Islam, \\ UIN Sunan Kalijaga, Yogyakarta \\ Email: mohamadyasinyusuf@ymail.com
}

Naskah diterima tanggal 27 Maret 2015 Naskah direvisi tanggal 07 April 2015 Naskah disetujui tanggal 02 November 2015

\begin{abstract}
Abstrak
Saat ini masyarakat telah berada di zaman modern. Nilai, norma dan ajaran agama dalam kehidupan masyarakat modern semakin memudar, dan diganti oleh pola hidup materialis serta penghambaan diri kepada kebendaan untuk mencapai kepuasan keduniaanya semata. Dari sinilah maka perlu digagas adanya konsep untuk menyeimbangkan antara kebutuhan duniawi dan kebutuhan ukhrowi melalui peningkatan ESQ (Emotional-Spiritual Quotient) dengan salah satu caranya melalui pengamalan Tarekat Qadiriyah wa Naqsyabandiyah sebagaimana yang dilakukan di Pondok Pesantren Miftahul Huda Malang. Penulisan artikel ini dilakukan melalui penelitian lapangan (field research) dengan model studi kasus yang menggunakan metode deskriptif dan dengan pendekatan kualitatif. Dari penelitian yang penulis lakukan diketahui bahwa dampak yang di timbulkan dari pengamalan Tarekat Qadiriyah wa Naqsyabandiyah di Pondok Pesantren Miftahul Huda Malang ini adalah terbentuknya akhlak Takhalli (membersihkan diri dari sifat-sifat tercela), Tahalli (menghiasi diri dari sifat-sifat yang terpuji), dan Tajalli (mencapai insan kamil). Dengan terbentuknya akhlak tersebut, seseorang akan mempunyai kecerdasan dalam melakukan hubungan dengan dirinya sendiri, hubungan dengan orang lain, lingkungan sosial, lingkungan sekitarnya dan semua itu didasari atas dasar nilai Ilahiyah. Hal inilah yang sebenarnya dapat di jadikan sebagai upaya dalam peningkatan ESQ (Emotional-Spiritual Quotient) masyarakat muslim di era modern.
\end{abstract}

Kata kunci: ESQ (Emotional-Spiritual Quotient), tarekat Qodiriyah wa Naqsabandiyah.

\begin{abstract}
Nowadays, people have been living in modern era. The values, the norms and the religion teaching in modern life society more and more decreased, and those were replaced by a materialistic lifestyle and selfservitude to the material to achieve the world satisfaction. Therefore, it was necessary to initiate the balance concept between worldly needs and hereafter needs through the increase of ESQ (Emotional-Spiritual Quotient). One of the ways was the application of Tarekat Qadiriyah wa Naqsyabandiyah as conducted in Miftahul Huda Islamic boarding school Malang. This article was written through field research with a case study model using descriptive method with qualitative approach. Through the research, the results were found that the impacts caused through the application of Tarekat Qadiriyah wa Naqsyabandiyah in Miftahul Huda Islamic boarding school in Malang were to make akhlak Takhalli (self-cleaning from the bad character), Tahalli (self-beautifying with praiseworthy character), and Tajalli (reaching the predicate as very kind man). With the formation of the characters, someone will have intelligence in the relationship within themselves, with others, with the social environment, with the surrounding environment and all of them were the underlying basis of the value of the Divine. This is what actually can be made in an effort to increase ESQ (Emotional-Spiritual Quotient) Muslim society in the modern era.
\end{abstract}

Keywords: ESQ (Emotional-Spiritual Quotient), tarekat Qodiriyah wa Naqsabandiyah, boarding school 


\section{PENDAHULUAN}

$\mathrm{S}$ aat ini mayarakat telah berada di zaman modern, kehidupan, tingkah laku, dan segala aktivitas menunjukkan kearah modernitas. Masyarakat yang modern identik dengan pemisahan dirinya dari kehidupan irrasional bahkan hal-hal yang di kategorikan sebagai non rasionalitas. Mereka hanya mengakui eksistensi dari hal-hal yang bersifat materiil dan yang dapat di raba, di rasa, di teliti dan ilmiyah (Hikmat Budiman, 1996: 38). Oleh karena itu nilai-nilai, norma dan ajaran agama semakin memudar, dan diganti oleh pola hidup materialis. Manusia modern yang seperti itu sebenarnya adalah manusia yang sudah kehilangan makna kehidupan yang sesungguhnya, maka banyak dari mereka yang mengidap gangguan kejiwaan antara lain berupa: kecemasan, kesepian, kebosanan, perilaku menyimpang, psikosomatis.

Meminjam istilah Ali Shariati, dalam buku ESQ karangan Ary ginanjar Agustian (2001: XX), bahwa manusia adalah mahluk dua dimensional yang membutuhkan penyelarasan kebutuhan akan kepentingan dunia dan akherat. Oleh karena itu manusia harus memiliki konsep duniawi atau kepekaan emosi dan intelegensia yang baik (EQ plus IQ), dan penting pula penguasaan ruhiyah vertikal atau Spiritual Quotient. Dalam buku yang lain, karangan H.M Idris Abu Shomad, (2005: 14), mengatakan bahwa Allah menciptakan manusia dari dua unsur yaitu tanah dan ruh, sebagaimana yang terkandung (Al Quran Surah Al Hijr: 28-29). Kemahabijaksanaan Allah juga dibuktikan dengan adanya keragaman fungsi pada setiap unsur tersebut. Jasad manusia yang merupakan unsur tanah yang terdiri dari tulang, daging, kulit, dan sebagainya berfungsi melaksanakan dan mengemban tugastugas hidup fisikal, pemenuhan kebutuhan keduniaan ada pada unsur ini. Selain itu unsur ruh yang ada pada diri manusia melingkupi unsur rohani, syu'ur (perasaan), dan potensi Ketuhanan, juga membutuhkan terpenuhinya kebutuhan dari ruh tersebut. Oleh karena itu, manusia harus bisa menyepadankan antara kebutuhan jamani dan ruhani, kebutuhan duniawi dan ukhrowi.

Dalam kehidupan modern inilah hendakya antara kebutuhan duniawi dan ukhrowi bisa berjalan bersama-sama. Oleh karena itu, dengan adanya konsep ESQ (Emotional-Spiritual Quotient) atau kecerdasan emosi dan kecerdasan spiritual, diharapkan antara kebutuhan duniawi dan ukhrowi tidaklah bertentangan namun mampu untuk berjalan bersama-sama dalam menghantarkan tujuan daan hakikat manusia yang sesunggguhnya. Dan dalam agama Islam sebenarnya terdapat cara untuk menyepadankan dua kebutuhan tersebut, cara inilah yang di sebut dengan jalan tarekat atau biasa di sebut dengan pola hidup bertasawuf. Ajaran dan amalan dalam tarekat akan menjadikan seseorang memiliki kepribadian yang tinggi baik dalam hubungan antar sesama manusia maupun dalam hubungan dengan Tuhannya.

Kecerdasan emosional atau yang sering di sebut dengan istilah Emotional Quotient (EQ), adalah kemampuan mengenali perasaan kita sendiri dan orang lain, kemampuan memotivi diri sendiri, dan kemampuaan mengelola emosi yang baik pada diri sendiri dan dalam hubungan dengan orag lain (Sudirman Tebba, 2003: 11-12). Dilihat dari perspektif sufistik, unsur-unsur kecerdasan emosional itu juga ada dalam ajaran tarekat. Misalnya ajaran dalam tarekat yang sesuai dengan konsep peningkatan emotional quotient yaitu muhasabah (melakukan perhitungan atau intropeksi diri), sabar (mampu mengelola emosi dengan baik), raja' (optimisme), itsar (mendahulukan kepentingan orang lain), syajaiah (ketrampilan sosial dan beraninya dalam menjalani kehidupan untuk berjuang bersama orang lain), dermawan berarti ada konsep untuk mempunyai harta terlebih dahulu. Dari sini berarti ajaran tarekat sebenarnya juga mengajarkan tentang bagaimana membangun kecerdasan emosional atau Emotional Quetient.

Pada pihak yang lain muncullah konsep Kecerdasan Spiritual (Spiritual Quetient) yang merupakan temuan terkini secara ilmiyah dengan ditemukannya eksistensi God-Spot dalam otak manusia sebagai pusat spiritual yang terletak di antara jaringan syaraf dan otak (Ary Ginanjar Agustian, 2001: xxxix). Hal ini menunjukkan bahwa secara kodrati alamiyah manusia telah memiliki potensi spiritual atau Ketuhanan, namun karena kadang-kadang manusia suka lalai dan terjerumus pada pemenuhan kebutuhan dari hawanafsu keduniaan, maka potensi ketuhanan tersebut tertutupi. Ketika mereka sudah dalam keadaan yang sangat membutuhkan dan berada pada jurang kehancuran dirinya maka potensi ketuhanan itu 
akan muncul kembali (Abdurrahman as Sanjari, 2004: 63). Dalam agama Islam di tawarkan suatu jalan yang dapat di lakukan untuk menumbuh kembangkan kembali kecerdasan spiritual yang semakin memudar dalam lingkungan kehidupan masyarakat muslim modern,cara tersebut yaitu tarekat. Maka saat ini banyak masyarakat modern yang melarikan diri pada ajaran tarekat (Abu Bakar Aceh, 1992:65).

Dari beberapa hal tersebut maka penelitian ini sangat menarik untuk dilakukan guna mengetahui bagaimana tarekat Qodiriyah wa Naqsabandiyah yang diajarkan di Pesantren Miftahul Huda Malang dapat dijadikan sebagai sarana dalam peningkatan kecerdasan emosional dan kecerdasan spiritual atau ESQ (Emotional-Spiritual Quotient).

Rumusan masalah yang diangkat adalah 1) Bagaimanakah kondisi masyarakat muslim yang mengamalkan Tarekat Qodoriyah wa Naqsabandiyah di Pondok Pesantren Miftahul Huda Malang? 2) Bagaimanakah upaya peningkatan ESQ (Emotional-Spiritual Quotient) melalui pengamalan Tarekat Qodoriyah wa Naqsabandiyah di Pondok Pesantren Miftahul Huda Malang?

Tujuan penelitian yakni untuk mengetahui kondisi masyarakat muslim yang mengamalkan Tarekat Qodoriyah wa Naqsabandiyah di Pondok Pesantren Miftahul Huda Malang dan mengetahui upaya peningkatan ESQ (Emotional-Spiritual Quotient) melalui pengamalan Tarekat Qodoriyah wa Naqsabandiyah di Pondok Pesantren Miftahul Huda Malang.

\section{Tinjauan Pustaka}

Penelitian sebelumnya yang terkait dengan peningkatan ESQ (Emotional-Spiritual Quotient) melalui pengamalan Tarekat Qodoriyah wa Naqsabandiyah antara lain: Skripsi dengan judul "pelaksanaan dakwah tarekat Qodiriyah wa Naqsabandiyah dalam pembinaan keagamaan santri Pondok Pesantren Darul Ulum Rejoso Petorangan Jombang" (Eli Sujarwo, 2010). Penelitian yang lain adalah Tesis dengan judul "Tarekat Qadiriyah wa Naqsabandiyah dalam Dakwah Islamiyah (Kontribusi TGH. L. M. Turmuzi Badaruddin dalam Dakwah Islmiyah di Lombok Tengah Nusa Tenggara Barat)" (Ahmad Zaini Dahlan, 2011). Penelitian yang lain berjudul "Tarekat Aliran Qadiriyah Wa Naqsabandiyah di Suryalaya Tasikrnalaya Jawa
Barat" (Sariyah, 2002). Dari beberapa penelitian sebelumnya tersebut, belum ada penelitian yang khusus mengaitkan antara pengaruh yang ditimbulkan oleh pengamalan Tarekat Qadiriyah wa Naqsabandiyah dalam meningkatkan ESQ (Emotional-Spiritual Quotient) masyarakat Muslim.

\section{METODE PENELITIAN}

Penelitian ini termasuk jenis penelitian lapangan (field research) dengan model studi kasus yang menggunakan metode deskriptif melalui pendekatan kualitatif (Arief Furchan, 1992: 2122). Maka disini peneliti akan memahami dan menafsirkan berbagaimacam hal yang terkait dengan cara peningkatan ESQ (EmotionalSpiritual Quotient) dalam Tarekat Qodiriyah wa Naqsabandiyah di Pondok Pesantren Miftahul Huda Malang.

Sumber data dalam penelitian ini adalah data utama dan data pendukung yang berasal dari katakata dan tindakan mursyid, kyai dan para santri, selebihnya ialah data pendukung seperti dokumen, kitab-kitab dan lain-lain (Lexy J. Moleong, 1999: 112). Dalam penelitian ini digunakan tiga teknik pengambilan data, yaitu: wawancara mendalam (indepth interview), observasi partisipan (partisipant observation), dan studi dokumentasi (study document) (Robert C. Bogdan dan Sari Knopp Biklen, 1998: 119-143). Sedangkan dalam analisis data digunakan teknik reduksi data (data reduction), sajian data (data display), penarikan kesimpulan dan verifikasi (conclusion drawing/ verification) (Matthew B. Miles, dan A. Michael Hubberman, 1992: 14). Sedangkan dalam hal kriteria keabsahan data, sebagaimana dalam penelitian kuantitatif kriteria keabsahan data harus memiliki validitas internal, validitas eksternal, reliabilitas dan obyektifitas, maka dalam penelitian kualitatif yang penulis lakukan ini juga meliputi uji credibility (validitas internal), transferability (validitas eksternal), dependability (reliabilitas), confirmability (obyektifitas) (Sugiyono, 2013: 364-374).

\section{PEMBAHASAN}

\section{Profil Pondok Pesantren Miftahul Huda Malang}

Pondok Pesantren Miftahul Huda Malang (lebih di kenal dengan sebutan Pondok Gading) yang berlokasi di tengah-tengah Kota Madya Malang, tepatnya di jalan Gading Pesantren No.38 
kelurahan Gading Kasri, Kecamatan Klojen, Kota Malang, Propinsi Jawa Timur. Sebagai Lembaga Pendidikan Islam, pesantren ini bisa di kategorikan sebagai lembaga yang sudah berumur tua, karena mengingat segi umur dari pesantren ini yang sudah mencapai dua abad lebih. Pesantren ini didirikan oleh al-Maghfurlah K.H Hasan Munadi pada abad $18 \mathrm{M}$, tepatnya pada tahun $1768 \mathrm{M}$.

Pondok Pesantren Miftahul Huda dari sejak didirikan hingga sekarang ini, bila diurutkan secara kronologis maka sudah berlangsung empat generasi kepemimpinan, kesemuanya itu adalah sebagai berikut:

Generasi pertama. Pada generasi pertama ini adalah generasi pendiri yang menjadi cikal bakal berdirinya pesantren Miftahul Huda Malang. Pondok ini awalnya hanya di kenal dengan sebutan Pondok Gading Malang yang pada tahun 1768-1858 dipimpin langsung oleh al-Magfurlah K.H. Hasan Munadi.

Generasi Kedua. Generasi kedua Pondok Gading Malang dipimpin oleh putra K.H. Hasan Munadi, yaitu K.H Muhyiddin yang juga dikenal dengan nama K.H Ismail. Estafet kepemimpinan generasi kedua ini berlangsung pada tahun 18581908.

Generasi Ketiga. Pada generasi ketiga ini Pondok Gading Malang dipimpin oleh K.H Muhammad Yahya, menantu dari K.H Ismail yang dinikahkan dengan putri angkatnya, yaitu Ny Siti Khadijah. Peristiwa itu terjadi pada tahun 1945 dan sejak itulah Pondok Gading diberi nama "Miftahul Huda". Pondok Pesantren Miftahul Huda Malang setelah dipimpin K.H Muhammad Yahya banyak mengalami perubahan dan kemajuan. Seiring dengan perkembangan zaman, maka beliau berani mengambil kebijakan baru yang belum pernah ada sebelumnya di pesantren ini, yaitu ketika beliau memberi restu dan ijin kepada santrinya untuk mengikuti pendidikan umum baik tingkat SD, SMP, SMA, maupun Perguruan Tinggi, yang ada di luar pesantren.

Generasi Keempat. Generasi keempat adalah periode yang saat ini sedang berlangsung, yang mana Pondok Pesantren Miftahul Huda dikelola oleh beberapa putra K.H Moh. Yahya dan menantu beliau, yaitu: K.H Abdurrahman Yahya (lahir 1945 dan beliau juga di ijazahi serta di beri mandat sebagai kholifah dan mursyid Tarekat Qodiriyah wa Naqsabandiyah, sebagai penerus Kyai Yahya bersama Kyai Abdul Adhim Yahya dan dalam idaroh Syu'biyah Jam'iyah Ahlith Thoriqoh Al Mu'tabaroh An Nahdliyah Malang, Kyai Abdurrahman di percaya sebagi Katib). Dan para pengasuh yang lain adalah K.H Ahmad Arif Yahya, K.H Moh. Baidlowi Muslich, K.H Shahibul Kahfi M.Pd. Dalam memimpin Pondok Pesantren Miftahul Huda Malang, mereka bertekad untuk tetap melestarikan dan mengikuti jejak sesepuh mereka, yaitu tetap melestarikan dan menjaga sistem dan nilai khas Pondok Pesantren Miftahul Huda Malang yang antara lain dengan tetap menggunakan system pendidikan salafiyah murni yang berbasiskan tasawuf dengan mengamalkan ajaran Tarekat Qodiriyah wa Naqsabandiyah tanpa melupakan kajian kitab-kitab fiqih dan ilmu syari’ah.

\section{Masyarakat yangMengamalkan Tarekat Qodiriyah wa Naqsabandiyah di Pondok Pesantren Miftahul Huda Malang}

Martin Van Bruinessen mengatakan bahwa kata tarekat (secara harfiyah berarti “jalan”) mengacu baik kepada sistem latihan meditasi maupun amalan (muroqobah, dzikir dan sebagainya) yang di hubungkan dengan sederet guru sufi dan organisasi yang tumbuh dalam metode tasawuf yang khas itu. Boleh juga di katakan bahwa tarekat itu sebenarnya mensistematiskan ajaran metode-metode tasawuf (Martin Van Bruinessen, 1992:15). Ada banyak macam tarekat yang telah berkembang antara lain Tarekat Qodiriyah wa Naqsabandiyah, Tarekat Sadziliyah, Tarekat Rifa'iyah, Tarekat Tijaniyah dan lain-lain.

Istilah tarekat Qodiriyah wa Naqsabandiyah mengacu kepada sebuah nama tarekat yang merupakan hasil rumusan atau formulasi Syeikh Ahmad Khatib Sambasi dari dua sistem tarekat yang berbeda (Qodiriyah dan Naqsabandiyah) menjadi satu metode tersendiri yang praktis untuk menempuh jalan spiritual. Beliau adalah putra bangsa Indonesia asli yang pernah menuntut ilmu di berbagi Negara Arab. Sehingga tidak aneh kalau kegiatan dakwahnya ini pertama kali di lakukannya sekitar abad ke-19 di Makkah. Seharusnya tarekat yang beliau dirikan ini dinamai "Tarekat Sambasiyah", karena sebagaimana kebiasaan pendiri tarekat yang lainya, selalu menamakan tarekat yang didirikanya dengan namanya sendiri. Namun 
Syaikh Ahmad Khotib Sambasi tampaknya tidak tertarik dengan hal itu, tetapi lebih suka menamai tarekatnya dengan sebutan Tarekat Qodiriyah wa Naqsabandiyah. Akhirnya istilah Qadiriyah wa Naqsyabandiyah oleh pengikutnya dijadikan semacam aliran yang sekarang kita kenal dengan nama "Tarekat Qadiriyah wa Nasyabandiyah". Syaikh Ahamad Khotib Sambasi tidak mengajarkan Tarekat Qodiriyah dan Naqsabandiyah secara terpisah, tetapi dalam satu kesatuan yang harus di amalkan secara utuh sekalipun masing-masing tarekat tersebut memiliki metode sendiri-sendiri yang sangat berbeda, baik dalam aturan-aturan kegiatan, prinsip-prinsip maupun cara-cara pembinaanya. Sehingga bentuk tarekat ini adalah tarekat baru yang memiliki perbedaan dengan kedua tarekat dasar itu (Ajid Thohir, 2002: 48-49).

Pondok pesantren Miftahul Huda Malang, selain menerapkan sistem salafiyah dalam pengajarannya, juga menerapkan pengamalan ajaran tarekat Qodiriyah wa Naqsabandiyah. Pengamalan tarekat ini sangat penting di lakukan karena dengan ajaran tarekat ini akan menambah kesempurnaan metode yang di terapkan di pesantren ini guna membentuk santri atau anak didik yang kamil. Pengaruh yang di timbulkan dari adanya amalan tarekat Qodiriyah wa Naqsabandiyah sangat besar sekali terutama dalam perbaikan akhlak dan sarana pendekatan diri kepada Allah swt.

Jama’ah yang mengikuti tarekat Qodiriyah wa Naqsabandiyah di pesantren ini terdiri dari masyarakat umum yang melingkupi seluruh wilayah Malang. Tidak hanya orang yang berumur diatas 40 tahun, tapi juga banyak para remaja dan orang dewasa yang mengikuti amalan tarekat di pesantren ini. Sedangkan khusus bagi santri, mereka juga di wajibkan mengikuti bai'at tarekat Qodiriyah wa Naqsabandiyah ini ketika mereka berada di kelas tiga ulya. Dalam pengajaran amalan tarekat Qodiriyah wa Naqsabandiyah di pesantren ini, masyarakat maupun santri sangat antusias dalam mengikutinya. Hal tersebut karena mereka telah merasakan adanya pengaruh yang sangat besar secara dhohiriyah maupun pengaruh secara bathiniyah. Kondisi masyarakat yang mengikuti tarekat Qodiriyah wa Naqsabandiyah di Pondok Pesantren Miftahul Huda Malang, secara umum dapat di klasifikasikan sebagai berikut:

\section{Dilihat dari segi perekonomian}

Dari segi perekonomian para pengamal tarekat Qodiriyah wa Naqsabandiyah di Pondok Pesantren Miftahul Huda Malang ini sangat variatif (bermacam-macam). Ada dari mereka yang berperekonomian tinggi (kaya), ada juga yang berperekonomian menengah (sederhana) dan ada juga yang berperekonomian rendah (kurang mampu). Namun mayoritas dari mereka adalah berperekonomian sedang (sederhana).

\section{Dilihat dari segi profesi}

Dari segi profesi, mayoritas dari mereka adalah wiraswasta, ada yang sebagai pedagang, ada juga yang mendirikan usaha kecil-kecilan di rumahnya . Namun juga banyak di antara mereka yang pegawai negeri dan orang-orang pemerintahan.

\section{Dilihat dari segi pendidikan}

Dari segi pendidikan para pengamal tarekat Qodiriyah wa Naqsabandiyah di pondok pesantren Miftahul Huda Malang bervariatif, namun banyak dari mereka yang telah memiliki pendidikan yang tinggi, karena mereka hidup dalam lingkungan yang telah maju. Mayoritas dari mereka adalah orang yang bermukim di wilayah kota Malang.

\section{Dilihat dari segi umur}

Masyarakat umum yang mengikuti tarekat di pesantren ini bervariatif, namun mayoritas dari mereka berumur 40 tahun, akan tapi tidak menutup kemungkinan juga banyak para remaja dan orang dewasa yang juga mengikutinya.

\section{Peningkatan ESQ (Emotional-Spiritual Quotient) Masyarakat Muslim}

Istilah kecerdasan emosional atau yang di kenal dengan EQ (Emotional Quotient) pertama kali di lontarkan pada tahun 1990 oleh Psikolog Peter Solovey dari Harvard University dan John Mayor dari University of New Hampshire, untuk menerangkan kualitas-kualitas emosional yang tampaknya sangatlah penting bagi keberhasilan (Laurence E. Shapiro, 1999: 5).

Kecerdasan emosional atau yang sering di sebut dengan istilah emotional quotient, melingkupi hal berikut (Daniel Goleman, 2003: 512):

a. Kesadaran diri, berarti mengetahui apa yang kita rasakan pada suatu saat dan menggunakanya 
untuk memandu pengambilan keputusan diri sendiri, memiliki tolak ukur yang realistis atas kemampuan diri dan kepercayaan diri yang kuat.

b. Pengaturan diri, berarti menangani emosi kita sedemikian sehingga berdampak positif terhadap pelaksanaan tugas, peka terhadap kata hati dan sanggup menunda kenikmatan sebelum tercapainya suatu sasaran, dan mampu pulih kembali dari tekanan emosi.

c. Motivasi, berarti menggunakan hasrat pada diri kita yang paling dalam untuk menggerakkan dan menuntun kita menuju sasaran, membantu kita mengambil inisiatif dan bertindak sangat efektif dan untuk bertahan menghadapi kegagalan serta flustrasi.

d. Empati, berarti merasakan sebagaimana yang di rasakan oleh orang lain, mampu memahami perspektif mereka, menumbuhkan hubungan saling percaya dan menyelaraskan diri dengan bermacam-macam orang.

e. Ketrampilan sosial, berarti menangani emosi dengan baik ketika berhubungan dengan orang lain dan dengan cermat membaca situasi dan jaringan sosial, berinteraksi dengan lancar, menggunakan ketrampilan-ketrampilan ini untuk mempengaruhi dan memimpin, bermusyawarah dan menyelesaikan perselisihan, dan untuk bekerja sama dan bekerja dalam suatu tim.

Sedangkan kecerdasan spiritual (spiritual quotient), merupakan temuan terkini yang secara ilmiyah pertama kali digagas oleh Danah Zohar dan Ian Marshal, masing-masing dari Harvard University dan Oxford University melalui riset yang sangat komprehensif. Pembuktian ilmiyah tentang SQ (Spiritual Quotient) ini, pertama, riset ahli Psikologi atau syaraf, Michael Persinger pada awal tahun 1990-an dan lebih mutakhir lagi tahun 1997 oleh ahli syaraf $V$. S. Ramachan dan timnya dari California University, yang menemukan eksistensi God-Spot dalam otak manusia sebagai pusat spiritual yang terletak di antara jaringan syaraf dan otak (Ary Ginanjar Agustian, 2001: xxxix). Spiritual quotient adalah pikiran yang mendapat inspirasi, dorongan, dan efektifitas yang terinspirasi, penghayatan ketuhanan yang didalamnya kita semua menjadi bagian (Sudirman Tebba, 2003: 1-2). Sedangkan dalam pandangan Islam SQ sebenarnya adalah sifat, sikap, dan perilaku takwa kepada Allah SWT, yang di buktikan dengan amal sholeh, yang di landaskan pada iman kepada Allah SWT (Idris Abdul Shomad, 2005: 22).

\section{Upaya Peningkatan ESQ (Emotional-Spiritual Quotient) melalui pengamalan Tarekat Qodoriyah wa Naqsabandiyah di Pondok Pesantren Miftahul Huda Malang}

Islam bukanlah agama yang memisahkan dunia dan akherat, tetapi bagaimana seseorang dapat menyeimbangkan keduanya. Untuk memperoleh kebahagiaan di akherat seseorang harus melalui dunia karena mereka memang hidup di dunia. Akhirnya bagaimana seseorang dapat menjadikan dunia sebagai kendaraan dalam mencapai kebahagiaan akherat (pengajian: KH. Abd Rahman Yahya). Penyesuaian antara dunia akherat inilah yang sebenarnya sangat di tekankan dalam pengajaran tasawuf atau tarekat. Ajaran tarekat secara umum adalah pengajaran aqidah yaitu dzikir kalimat istmu dzat Allah ataupun laa ilaaha illallah, yang di baca secara istiqomah setiap selesai sholat maktubah dan pengajaranya tentang bagaimana mempunyai akhlak yang baik dan menghilangkan akhlak yang jelek serta ajaranya tentang bagaimana melalui akhlak tersebut mereka dapat melakukan hubungan yang baik bagi dirinya sendiri, diri sendiri dengan orang lain, maupun diri sendiri dengan Allah swt. Ajaran inilah yang telah di letakkan oleh Rasulullah saw sebagai ajaran kehidupan yang harus di amalkan oleh setiap orang Islam. Sehingga denganya umat Islam akan maju dan jaya serta mempunyai generasi-generasi yang akan mampu mengubah dunia dari gelap gulita menjadi penuh bercahaya dan selalu mendapatkan ridho Allah swt.

Untuk memperoleh keberhasilan dalam menjalani kehidupan, sebagaimana penelitian para ahli, bahwa seseorang haruslah mempunyai kecerdasan emosional sekaligus kecerdasan spiritual atau yang di kenal dengan ESQ (EmotionalSpiritual Quotient). Dari penelitian yang penulis lakukan ternyata kedua kecerdasan tersebut dapat di kembangkan melalui pengamalan tarekat Qodiriyah wa Naqsabandiyah, karena memang keduanya mempunyai perspektif yang sama.

Lebih lanjut, KH. Baidhowi Muslih (wawancara, pengasuh Pesantren Miftahul Huda) mengatakan bahwa ajaran tarekat Qodiriyah wa 
Naqsabandiyah yang di kembangkan di pondok pesantren Miftahul Huda Malang, bukan hanya sebuah ajaran ritual belaka, tetapi mempunyai makna yang maha penting dalam membangun kecerdasan Emosi dan kecerdasan spiritual atau yang di kenal dengan ESQ (Emotional-Spiritual Quotient), karena ternyata pokok pikiran yang ada di dalam ajaran ini, juga memberikan bimbingan untuk mengenal dan memahami perasaan kita sendiri dan perasaan orang lain, menjalani hubungan dengan orang lain sekaligus dengan Tuhanya, memotivasi diri, serta mengelola emosi dalam berhubungan dengan orang lain, yang di latih melalui pengajaranya dalam menumbuhkan sifat takhalli, tahalli, dan tajalli.

Dari sejarahnya saja menunjukkan bahwa tarekat Qodiriyah wa Naqsabandiyah dapat di jadikan sebagai wahana dalam menumbuhkan ESQ. KH Abdur Rahman Yahya (wawancara, Mursyid Tarekat Qodiriyah wa Naqsabandiyah) menceritakan bahwa, sejarah dari tarekat Qodiriyah adalah berasal dari sahabat Ali r.a yang mendapatkan bai'at langsung dari Rasulullah saw. Kejadianya adalah ketika ada seorang sahabat yang datang kepada Nabi, kemudian dia mengatakan bahwa rukun Islam telah dia laksanakan, akan tetapi untuk rukun Islam yang berhubungan dengan membayar zakat dan jihad belum mampu dia lakukan. Hal tersebut karena sahabat tersebut hanya memegang agama secara syar'iahnya saja dan belum sampai kepada ruh agama atau maqom hakikat. Oleh karena itu, ketika itu juga yang sahabat Ali r.a berada di samping Nabi Muhammad saw langsung di pegang tangannya dan di bai'at dengan kalimat Laa Ilaha Illallah dengan bersuara keras, agar dapat mencapai maqom hakikat sehingga ajaran Islam apapun akan di laksanakan dengan penuh kesadaran dan penuh penyandaran diri kepada Allah swt, tanpa merasa berat sedikitpun. Pembaiatan dari Rasulullah saw kepada sahabat Ali r.a inilah yang merupakan cikal bakal dari pengamalan tarekat Qodiriyah yang di anggap sebagai dasar dari suatu amalan yang datangnya langsung dari Rasulullah saw, ajaranya bukanlah ajaran bid'ah dan tidak berdasar kepada sunah Rasulullah saw.

Peristiwa tersebut secara garis besar dapat di jelaskan bahwa sahabat yang datang kepada Rasulullah saw dengan mengatakan bahwa rukun Islam yang berupa zakat dan jihad belum mampu dia lakukan, menunjukkan bahwa dirinya masih kurang mempunyai kepakaan sosial sekaligus masih kurangnya keimanan dan ketakwaannya kepada Allah. Inilah yang menunjukkan bahwa dirinya masih belum mempunyai ESQ (Emotional-Spiritual Quotient) yang tinggi. Dirinya masih mengerjakan amal dan aktifitas beragama secara dhohirnya saja. Amalnya masih belum sampai kepada kesadaran diri dan hakikat dari beragama itu sendiri. Oleh karena itu Rasulullah saw saat itu juga membaiat sahabat Ali r.a, untuk meningkatkan amal ibadahnya sampai kepada hakikat keberagamaan yang sebenarnya. Sehingga pada akhirnya amalan Islam baik yang berupa zakat, jihad dan amal-amal yang lainnya dapat di laksanakan dengan penuh kesadaran diri dan keimanan serta ketaqwaan kepada Allah saw. Inilah yang menunjukkan potensi ESQ (EmotionalSpiritual Quotient) telah tumbuh dan berkembang secara baik.

Sedangkan untuk tarekat Naqsabandiyah di lihat dari sejarahnya, juga menunjukkan bahwa tarekat ini mempunyai hubungan dalam peningkatan ESQ (Emotional-Spiritual Quotient). Tarekat Naqsabandiyah amalannya berasal dari Abu Bakar r.a, beliau menerima pelajaran spiritualnya pada malam hijrah, ketika ia dan Rasulullah SAW sedang bersembunyi di sebuah gua tak jauh dari Makkah. Ketika dikejar musuh dan bersembunyi di gua itu, kondisi emosi dan psikologi Abu Bakar r.a tidak tenang. Beliau merasa takut dan seluruh tubuhnya bergetar. Hal tersebut karena disekeliling gua banyak terdapat musuh yang siap untuk membunuh mereka berdua. Dalam kondisi seperti itu, Rasulullah saw mengatakan "janganlah engkau takut, karena sesungguhnya Allah bersama kita”. Dan saat itu juga Rasulullah saw mengajarinya untuk berdzikir dalam hati dengan kalimat Allah. Dzikir diam dan sikap-sikap spiritual yang lainya inilah yang di percayainya kaum Naqsabandy telah di turunkan Rasulullah saw kepada Abu Bakar yang kemudian berlanjut kepada murid-muridnya, dan akhirnya di jadikan sebuah sistem oleh Syaikh Baha' Al Din An Naqsabandy menjadi sebuah aliran tarekat yang di kenal dengan Naqsabandiyah.

Dari peristiwa tersebut menunjukkan bahwa sebelum sahabat Abu Bakar r.a mendapat bai'at dan pengajaran spiritual dari Rasululah saw, kondisi psikologi dan emosionalnya masih belum bisa terkendali secara baik, demikian juga penyandaran diri dan tawakal kepada Allah SWT masih kurang. 
Hal ini menunjukkan bahwa kecardasan emosi dan spiritual atau ESQ (Emotional-Spiritual Quotient) masih kurang. Sedangkan setelah beliau mendaptkan baiat dan pengajaran spiritual dari Rasulullah saw maka ESQ (Emotional-Spiritual Quotient) beliau semakin meningkat dengan baik.

Setelah melihat dari sejarahnya, maka saat ini penulis mencoba mengkaji lebih dalam tentang pengamalan tarekat Qodiriyah wa Naqsabandiyah khususnya yang ada di pondok pesantren Miftahul Huda Malang dalam hubunganya dengan peningkatan ESQ (Emotional-Spiritual Quotient) bagi masyarakat muslim yang saat ini berada di era atau zaman modern.

Pengamalan tarekat Qodiriyah wa Naqsabandiyah di pondok pesantren Miftahul Huda Malang yang akan menumbuhkan kecerdasan emosional dan kecerdasan spiritual antara lain dapat di lakukan dengan:

\section{Peningkatan ESQ (Emotional-Spiritual Quotient) melalui pengamalan dzikir yang di lakukan secara kontinyu (istiqomah).}

KH. Baidhowi Muslich (wawancara, pengasuh pesantren Miftahul Huda Malang) mengatakan bahwa pengamalan dzikir dalam tarekat Qodiriyah dilakukan dengan keras (yakni bersuara keras). Dzikir utama dalam tarekat ini adalah La Ilaha illallah, yang di baca secara istiqomah setiap selesai sholat maktubah sebanyak 165 kali. Sedangkan amalan dzikir dalam tarekat Naqsabandiyyah merupakan dzikir tahap kedua setelah tarekat Qadiriyah. Dzikir ini di sebutkan sebagai dzikir itsmu dzat, yaitu dzikir dengan lafadz Allah di dalam hati (Dzikrul Qalbi) yang di baca secara berulangulang.

Setelah seseorang masuk tarekat, ternyata amaliyah tarekat tersebut membawa dampak terhadap perubahan tingkah laku (akhlaq), ini disebabkan oleh adanya pengaruh dzikir yang begitu kuat dan di lakukan secara istiqomah, yang mempengaruhi jiwa penganut tarekat. Secara singkat dapat di jelaskan bahwa dzikir yang di lakukan dalam ajaran tarekat ini di lakukan dengan cara sang dzakir (orang yang melantunkan dzikir) duduk seperti dalam shalat sambil menghadap kiblat dan harus menutup matanya sambil mengkonsentrasikan fikiranya kepada Allah. Kemudian mengucapkan kata $L a$ sembari menarik bunyi seperti dari pusar, mengangkatnya kebahunya, kemudian mengucapkan Ilaha sambil menarik bunyi dari otaknya. Sesudah itu, ia mestilah mengetukkannya, yakni mencamkan kata-kata Illa Allah dengan kuat dalam hatinya, seraya memikirkan bahwasanya Allah sajalah sang kekasih, dan bahwa nama Allah sajalah wujud hakiki dan tujuan hakiki dalam kehidupan. Pelafadzan kalimat laa ilaha illallah tersebut melewati latifatus sabah yang merupakan tempat akhlak yang baik dan tempat akhlak yang jelek. Dengan selalu memasukkan lafadh laa ilaha illallah pada tempat-tempat latifatus sabiah tersebut maka akan menimbulkan akhlak mahmudah (akhlak terpuji) dan menghilangkan akhlak madzmumah (akhlak tercela). Sehingga akhirnya mereka akan mempunyai kecerdasan akhlak baik secara pribadi maupun secara sosial. Dengan adanya akhlak tersebut berarti potensi ESQ (EmotionalSpiritual Quotient) seseorang dengan sendirinya akan semakin meningkat. Karena pada intinya ESQ merupakan suatu konsep dalam pembentukan kecerdasan akhlak pribadi dan akhlak sosial yang di sandarkan kepada nilai Ketuhanan.

KH. Abdur Rahman Yahya (wawancara, Mursyid tarekat Qodiriyah wa Naqsabandiyah), juga menjelaskan tentang pengaruh yang di dapatkan ketika seseorang mengamalkan dzikir secara istiqomah yaitu menjadikan orang tersebut khusyu' dalam sholatnya. Karena kebiasaan dzikir yang mereka lakukan akan menghindarkan mereka dari perbuatan-parbuatan yang tercela, sekaligus dzikir juga dapat menghapuskan dosa-dosa mereka, sehingga menjadikan hati dan fikiran mereka bersih. Ketika hati dan fikiran mereka bersih maka akan menjadikan sholat mereka bisa lebih terkonsentrasi kepada Allah dan menjadikanya khusyu.' Khusyu' dalam sholat juga perlu di lakukan, karena dengan khusyu' tersebut maka pengaruh dari sholat akan nampak pada diri orang tersebut. Sebagaimana yang di sebutkan dalam Al Qur'an, yang artinya "Sesungguhnya sholat itu akan mencegah dari perbuatan yang keji (fakhsya') dan tercela (mungkar)". Di sinilah perlunya melakukan sholat dengan khusyu'. Saat ini banyak orang Islam yang walaupun mereka melakukan sholat namun aktifitas kehidupan mereka sangat jauh dari normanorma kebaikan, mereka masih suka melakukan kejahatan, mereka masih suka mengganggu orang lain dan berbagai macam aktifitas kehidupan yang 
menggambarkan mereka bukanlah orang yang beradab dan bahkan seperti tidak beragama. Kondisi inilah yang mungkin terjadi karena walaupun orang tersebut melakukan aktifitas sholat namun sebenarnya mereka tidak melakukanya. Aktifitas sholat yang mereka lakukan hanya terlihat secara dzohir tanpa menembus batin mereka. Di sinilah perlunya melakukan sholat secara khusyu' sehingga pengaruh dari sholat tersebut sampai kepada seluruh aktifitas kehidupan mereka yang menjadi baik. Pengaruh dari sholat yang khusyu' inilah yang menjadikan seseorang akan bisa di terima oleh lingkungan masyarakatnya, karena orang tersebut akan selalu berbuat baik dan mampu meninggalkan perbuatan keji dan mungkar. Hal ini berarti orang tersebut telah memiliki ESQ (Emotional-Spiritual Quotient) yang tinggi.

Pengaruh dari dzikir dalam Tarekat Qodiriyah wa Naqsabandiyah yang lainya yang dapat meningkatkan ESQ yaitu sebagaimana wawancara yang penulis lakukan dengan Bapak $\mathrm{H}$ Sucipto (wawancara, murid pengamal tarekat Qodiriyah wa Naqsabandiyah), beliau menceritakan bahwa dampak yang ditimbulkan oleh pengamlan dzikir yang ada pada tarekat itu begitu besar dalam pencapaian keberhasilan kehidupan, antara lain: dengan sendirinya akan membentuk akhlak yang baik sehingga mampu melakukan hubungan baik dan dicintai oleh orang lain, oleh karena itu usaha dan pekerjaan yang dilakukan akan menjadi lancar dan selalu mendapatkan dukungan dari orang lain. Salah satu buktinya adalah usaha yang di lakukan beliau yang berupa percetakan dan sablon semakin maju dan meningkat, bahkan saat ini beliau sudah mempunyai 36 karyawan. Beliau juga menceritakan bahwa dizikir dan amalan tarekat tidaklah menghalangi kesuksesan dalam melakukan suatu usaha. Dzikir yang selalu di ucapkan di manapun (dengan dzikir sirri) akan semakin meningkatkan kepercayaan diri, penyandaran diri kepada Allah yang berarti tidak takabur dan tidak bertingkah laku sekehendaknya, hati akan bisa lebih tenang sehingga pekerjaan akan berjalan dengan lancar, dan masih banyak lagi dampak positif yang timbul dari melakukan dzikir secara terus-menerus (dzikir sirri), yang kesemuanya tersebut ternyata bisa menimbulkan dampak positif terhadap keberhasilan suatu usaha dan pekerjaan.

\section{Peningkatan ESQ (Emotional-Spiritual Quotient) melalui pencapaian tingkatan maqom lathifah sab'ah.}

KH. Baidhowi Muslich (wawancara, pengasuh pesantren Miftahul Huda Malang) mengatakan bahwa tingkatan lathifah sabah haruslah di lalui oleh seorang salik. Dengan tingkatan tersebut seorang salik akan semakin mampu mendekatkan diri dengan Allah SWT serta dengan sendirinya akan menimbulkan akhlaq mahmudah (akhlak terpuji) dan menghilangkan akhlak madzmumah (akhlak tercela), yang dengan kata lain berarti ESQ (Emotional-Spiritual Quotient) seorang salik dengan sendirinya juga akan semakin meningkat. Latifah Sabah tersebut adalah:

\section{Lathifatul Qolbi}

Merupakan kehalusan hati dengan terhapusnya nafsu lawwamah yang berjumlah sembilan, yaitu: suka mencela, mengumbar hawa nafsu, munafik, sombong, ghibah, riya, namimah, bohong dan lupa ibadah. Sasaran dzikirnya adalah susu kiri kurang lebih dua jari agak ke kiri sedikit, sebab di situ ada lubang dan selaput putih atau ainul bashiroh sebagai tempat syaitan. Dengan terhapusnya nafsu lawwamah tersebut berarti ESQ (Emotional-Spiritual Quotient) seseorang akan tumbuh.

\section{Lathifatul Ruh}

Merupakan kehalusan ruh yang akan memunculkan nafsu mulhimah yang berjumlah tujuh, yaitu: dermawan, qona'ah, rendah diri, senang taubat, sabar, berserah diri. Sasaran dzikirnya adalah di bawah susu kanan kurang lebih dua jari agak ke kanan sedikit. Dengan munculnya nafsu mulhimah tersebut berarti seseorang juga akan mempunyai kecerdasan emosional antara lain mempunyai ketrampilan sosial yang baik yang di gambarkan oleh sikap dermawannya, mempunyai kesadaran diri dan pengaturan diri yang di gambarkan oleh sikapnya yang qonaah, rendah diri, dan sabar. Mereka juga akan mempunyai kecerdasan spiritual yang di gambarkan oleh sikapnya yang senag bertaubat dan hanya berserah diri kepada Allah swt.

\section{Lathifatul Sirri}

Merupakan kehalusan perasaan yang akan memunculkan nafsu mutmainnah, meliputi enam 
macam, yaitu: dermawan, pasrah atau berserah diri kepada Allah, ikhlas, istiqomah, syukur, ridho dan takut maksiat. Sasaran dzikirnya adalah di atas susu kiri kurang lebih dua jari agak ke kanan sedikit. Dengan munculnya nafsu mutmainnah tersebut berarti seseorang secara otomatis juga akan mempunyai ESQ (Emotional-Spiritual Quotient) yang tinggi, hal ini karena mereka akan mampu berhubungan dengan baik secara vertikal maupun horizontal.

\section{Lathifatul Khofi}

Merupakan kehalusan kepada sesuatu yang samar dengan bertambahnya nafsu mardiyah yang meliputi enam macam, yaitu: akhlak baik, gemar beribadah, mempunyai sifat belas kasihan kepada siapapun, suka mengajak beribadah kepada orang lain, pema'af dan pemberi nasihat. Sasaran dzikirnya adalah susu kanan kurang lebih dua jari agak ke kiri. Dengan munculnya nafsu mardiyah tersebut berarti seseorang akan mampuanyai kesalehan sosial dengan baik dan sikap tersebut senantiasa di sandarkan kepada nilai Ilahiyyah. Ini merupakan indikasi tumbuhnya ESQ (Emotional-Spiritual Quotient) pada diri seseorang dengan baik.

\section{Lathifatul Akhfa'}

Merupakan kehalusan kepada sesuatu yang lebih samar yang tergolong nafsu kamilah, yang meliputi: pandai berfikir, yakin ketika membayangkan, dan yakin kepada sesuatu untuk mengamalkanya. Sasaran dzikir ini adalah pada tengah-tengah dada. Dengan munculnya nafsu kamilah ini, berarti IQ (Intelegency Quotient) seseorang akan semakin meningkat karena mereka akan semakin pandai berfikir dan cerdas. Selain itu mereka juga akan mempunyai EQ atau kecerdasan emosional yang tinggi yang di tunjukkan oleh tindakan keyakinan akan keberhasilan dan pengamalannya terhadap segala sesuatu. Penguasaan ruhiyyah vertikal atau kecerdasan sapiritual mereka di pastikan juga akan meningkat.

\section{Lathifatul Nafsi}

Merupakan kehalusan otak untuk berfikir dengan terangkatnya sifat amarah bissu' yang meliputi: kikir, tamak, dengki, bodoh, sombong, pemarah, dan hanyut kepada hawa nafsu. Sasaran dzikirnya adalah: di antara kedua mata dan kedua kening (alis) sampai pada pokoknya otak. Ketika seseorang telah mencapai tingkat ini, berarti potensi IQ, EQ, maupun SQ secara bersamaan akan semakin meningkat, karena unsur-unsur pembangunnya juga terdapat dalam tingkatan latifatul nafsi ini.

\section{Lathifatul Qolb}

Merupakan kehalusan anggota badan dengan munculnya nafsu rodiyah yang meliputi: dermawan, pandai menyimpan harta untuk beribadah, ikhlas, giat beribadah, dan istiqomah terhadap hasil bai'at maupun ibadah-ibadah yang lainya. Sasaran dzikirnya adalah mulai dari ujung rambut kepala sampai pada ujung kaki. Pada tingkatan ini ESQ (Emotional-Spiritual Quotient) seseorang akan semakin meningkat, karena mereka mengetahui bagimana harus melakukan hubungan baik dengan dirinya sendiri, dengan orang lain dan lingkungan sekitarnya ataupun dengan Allah swt.

Dengan selalu memasukkan lafadh dzikir laa ilaha illallah pada tempat-tempat latifatus sab'ah tersebut maka akan menimbulkan akhlak mahmudah (akhlak terpuji) dan menghilangkan akhlak madzmumah (akhlak tercela). Sehingga akhirnya mereka akan mempunyai kecerdasan akhlak baik secara pribadi maupun secara sosial. Dengan adanya akhlak tersebut berarti potensi ESQ (Emotional-Spiritual Quotient) seseorang dengan sendirinya akan semakin meningkat. Karena pada intinya ESQ merupakan suatu konsep dalam pembentukan kecerdasan akhlak pribadi dan akhlak sosial yang di sandarkan kepada nilai Ketuhanan. Sikap inilah yang akan membantu seseorang untuk mampu bersifat lebih toleransi, terbuka atas perbedaan, memiliki empati tinggi dan mau bekerjasama dengan orang lain, motivasi kesuksusan hidup yang tinggi, dan kemampuan dalam melakukan manajerial diri dan sosial dengan baik, sehingga akan mampu mewujudkan kehidupan masyarakat yang baik.

\section{Peningkatan ESQ (Emotional-Spiritual Quotient) melalui pembentukan Akhlak At Takhalliyah, At Tahalliyah, dan At Tajalliyah}

Dalam tarekat, salah satu dari pada persoalan yang terpenting didalamnya adalah memperbaiki akhlak. Dengan akhlak tersebut seseorang akan mampu melakukan menejemen dirinya dengan baik, mampu hidup dan berhubungan dengan orang 
lain secara baik, dan akhirnya juga mampu serta mempunyai hubungan secara vertikal Ilahiyyah dengan baik pula. Dari akhlak inilah sebenarnya kecerdasan emosional dan spiritual atau ESQ (Emotional-Spiritual Quotient) seseorang akan muncul dan berkembang dengan baik. Pengajaran akhlak tersebut menurut KH. Abdur Rahman Yahya (wawancara, Mursyid tarekat Qodiriyah wa Naqsabandiyah), antara lain dapat dilakukan dengan belajar mengamalkan dan memiliki sifat di bawah:

Sifat Takhalli yaitu mempunyai arti membersihkan diri dari sifat-sifat tercela. Seperti hasad (iri hati), naqad (dengki atau benci), su'udzan (buruk sangka), kibir (sombong), ujub (merasa sempurna dari orang lain), riya' (memamerkan kelebihan), sama' (cari nama), bakhil (kikir), namimah (berbicara dibelakang orang). Sifatsifat dan tindakan yang tercela itulah yang akan mengakibatkan seseorang tidak mempunyai ESQ (Emotional-Spiritual Quotient) yang tinggi, atau dengan kata lain tidak memiliki kecerdasan emosional, apalagi kecerdasan spiritual. Karena dengan sifat sifat tersebut seseorang di pastikan tidak akan mampu melakukan hubungan yang baik dengan dirinya sendiri, hubungan yang baik dengan masyarakat dan lingkungan sekitarnya, lebih-lebih dalam hubungan dengan Tuhan-nya. Oleh karena itu menghilangkan sifat dan tindakan tercela, yang salah satunya di lakukan melalui pengajaran tarekat Qodiriyah wa Naqsabandiyah ini menjadi sangat penting.

Sifat Tahalli mempunyai pengertian menghiasi atau mengisi diri dengan sifat-sifat terpuji. Seperti taubat (menyesali diri dari perbuatan tercela), khauf (perasaan takut kepada Allah), takwa (penyandaran segala sesuatu hanya kepada Allah), ikhlas (niat amal yang tulus atau suci), sabar (tahan diri dari kesukaran), ridho (bersenang diri menerima putusan Tuhan), mahabbah (perasaan cinta kepada Allah semata-mata), zikrul maut (selalu ingat akan mati), itsar (lebih mengutamakan kepentingan orang lain), dermawan (suka memberi) dan lain sebagainya. Jika seseorang telah mampu menghiasi dirinya dengan sifat-sifat terpuji, maka mereka akan mudah melakukan hubungan dengan orang lain, mereka akan di cintai oleh orang lain, dan Allahpun pasti akan meridhoinya. Dalam hal ini, mereka akan ihklas hati dan niatnya selalu tertuju untuk mencari ridho dan melakukan ibadah hanya kepada Allah. Mereka akan ikhlas dalam mengabdi kepada masyarakat, ikhlas bekerja untuk kepentingan agama, bangsa dan negara. Ikhlas memberikan pertolongan dan bantuan, kepada siapapun dan kapanpun waktunya. Sifat terpuji dan tindakan yang demikianlah, yang menunjukkan seseorang mempunyai ESQ (Emotional-Spiritual Quotient) yang baik.

Sifat Tajalli berati suatu maqom yang mana Allah menjadi jelas dalam ilmu dan kehidupan jiwa, hijab tersingkap, atau pengaruh pancaran Illahi yang mengandung berkah akan memancar atas dirinya yang di berkati, karena telah melewati maqom takhalli dan tahalli. Dalam hal ini berarti orang yang mempunyai akhlak tajalli akan mempunyai derajat yang tinggi baik di mata manusia maupun di hadapan Allah SWT. Dengan munculnya sifat tajalli tersebut berarti seseorang telah menumbuhkan potensi ESQ (EmotionalSpiritual Quotient) dalam dirinya secara sempurna. Meraka akan senantisa memberikan kasih sayang kepada seluruh umat manusia, sebagaimana sifat Allah yang maha memberikan kasih sayang kepada seluruh hambanya tanpa terkecuali. Dan dari sinilah maka akan mampu dibangun kehidupan yang lebih inklusif (saling menyayangi, menghormati dan bekerjasama dalam kebaikan) dan tidak lagi bersifat eksklusif (radikal, anarkis dan selalu merasa benar sendiri).

\section{Peningkatan ESQ (Emotional-Spiritual Quotient) melalui ritul-ritual keagamaan yang lainya.}

Ritual-ritual yang di lakukan dalam tarekat Qodiriyah wa Naqsabandiyah di Pon-Pes Miftahul Huda Malang, antara lain: Khushusiyah, Istighatsah, dan pembacaan manaqib Syaikh Abdul Qodir Al Jailani. Manfaat yang dapat di ambil dari kegiatankegiatan tersebut tidak sekedar untuk pemenuhan kebutuhan rohani saja, namun banyak memberikan manfaat yang lain, misalnya: dengan adanya kegiatan tersebut akan menambah hubungan dan kedekatan antar jama'ah tarekat, sehingga apabila salah satu dari mereka ada yang mempunyai permasalahan hidup maka yang lain dapat membantunya, selain itu melalui kegiatan-kegiatan tersebut dapat digunakan sebagai sarana dalam penggalian dana, yang nantinya akan digunakan untuk membangun masjid, menyantuni anak yatim, membantu orang 
fakir miskin dan untuk kegiatan sosial yang lainya. Dalam hal ini berarti kegiatan-kegiatan seperti manaqib Syaikh Abdul Qodir Aljailani, Khususiyah, dan Istighotsah serta kegiatan yang lainya, tidaklah hanya terfokus untuk kegiatan ritual belaka, tetapi manfaat yang lebih dari itu sebenarnya juga mampu untuk menumbuhkan ESQ (Emotional-Spiritual Quotient). Karena dengan kegiatan tersebut mereka akan mampu melakukan hubungan baik dengan orang lain sekaligus hubungan dengan Allah.

Selain itu, yang menarik dari kegiatan ritual ini dalam hubunganya dengan peningkatan ESQ (Emotional-Spiritual Quotient) menurut $\mathrm{KH}$. Abdur Rahman Yahya (wawancara, Mursyid tarekat Qodiriyah wa Naqsabandiyah), adalah adanya bacaan-bacaan asmaul husna maupun ayat-ayat Al Qur'an tertentu yang dibaca ketika ritual ini dilaksanakan. Menurut beliau, teryata amalanamalan dzikir khusus tersebut mampu membawa dampak dalam menumbuhkan ESQ (EmotionalSpiritual Quotient) seseorang. Asmaul husna merupakan nama dan sifat Allah yang maha agung yang terdapat dalam Al Qur'an. Ternyata asmaul husna merupakan sumber dari segala suara hati seseorang (God-Spot), yang mampu menumbuhkan ESQ (Emotional-Spiritual Quotient) dari orang yang mampu meresapi dan mencari hakikat makna di dalamnya. Misalnya, dengan menggunakan acuan sifat Allah yang berupa ar-Rahman maka seseorang akan mampu menumbuhkan dorongan suara hati yang berupa sikap mau mengasihi dan bersikap kasih sayang terhadap orang lain, dengan acuan sifat Allah yang berupa al-Kholiq maka seseorang akan mampu menumbuhkan dorongan dalam hatinya yang berupa sikap kreatif dan ingin menciptakan hal-hal yang baru, dengan acauan sifat Allah yang berupa as-Sami' maka akan tumbuhlah sikap mau mendengarkan dan memahami orang lain (empati), dengan acuan sifat Allah yang berupa al-Qowiyyu maka akan tumbuhlah sikap untuk memiliki kekuatan dan semangat yang tinggi dalam melakukan berbagai macam aktifitas kehidupan serta tidak mudah menyerah. Demikian halnya dengan menggunakan acuan sifat-sifat Allah yang lainya yang berjumlah 99 (asmaul husna), maka seseorang akan mampu menumbuhkan dorongan dalam hatinya untuk berbuat dan beraktifitas dalam kehidupan sehari-hari sesuai dengan sifat Allah tersebut. Hal inilah yang menunjukkan bahwa dengan pengamalan asmaul husna tersebut, maka ESQ (Emotional-Spiritual Quotient) meraka secara tidak langsung juga akan meningkat.

Dari penjelasan di atas tentang pengamalan tarekat Qodiriyah wa Naqsabandiyah di pondok pesantren Miftahul Huda Malang dalam upaya meningkatkan ESQ (Emotional-Spiritual Quotient) masyarakat muslim, penulis dapat mengambil benang merah bahwa ternyata pengamalan tarekat tersebut dapat dijadikan sebagai upaya dalam meningkatkan kecerdasan emosional dan spiritual masyarakat muslim yang hal tersebut memang sangat dibutuhkan, karena mereka saat ini sedang berada di zaman modern yang penuh dengan kerusakan dalam berbagai bidang kehidupan.

Bila ditelusuri dari kondisi zaman ini, memang masyarakat modern identik dengan pemisahan dirinya dari kehidupan irrasional bahkan halhal yang di kategorikan sebagai non-rasionalitas. Mereka hanya mengakui eksistensi dari hal-hal yang bersifat materiil dan yang dapat diraba, dirasa, diteliti dan ilmiyah. Oleh karena itu, nilai-nilai, norma dan ajaran agama dalam kehidupan masyarakat modern semakin memudar, dan diganti oleh pola hidup materialis dan menghambakan diri kepada kebendaan untuk mencapai kepuasan keduniaanya semata. Hal inilah yang akan mengakibatkan kerusakan dalam berbagai bidang kehidupan. Dari kondisi tersebut maka sangat di butuhkanlah adanya kecerdasan emosional dan kecerdasan spiritual bagi seluruh masyarakat muslim yang saat ini sedang berada di zaman modern.

Dari penelitian yang penulis lakukan ternyata pengamalan tarekat Qodiriyah wa Naqsabandiyah mampu dijadikan sarana dalam peningkatan meningkatkan ESQ (Emotional-Spiritual Quotient). Dengan dua kecerdasan tersebut (EQ plus SQ) maka masyarakat muslim akan mampu menyesuaikan dan menyepadankan antara kebutuhan duniawi dan kebutuhan ukhrowi. Mereka tidaklah terjerumus dalam kehidupan yang semakin rusak, akan tetapi mereka akan mampu membawa dirinya tetap berada dijalan kebenaran. Sehingga mereka akan selamat di dunia dan akherat.

\section{PENUTUP}

Ajaran tarekat Qodiriyah wa Naqsabandiyah yang ada di Pondok Pesantren Miftahul Huda Malang ternyata tidak hanya berperan sebagai sebuah 
ajaran ritual belaka, tetapi mempunyai peran yang penting dalam membangun kecerdasan emosional dan kecerdasan spiritual atau ESQ (EmotionalSpiritual Quotient), karena pokok pikiran yang ada didalam tarekat ini akan memberikan bimbingan untuk mempunyai kecerdasan akhlak pribadi dan sosial, mampu melakukan manajemen pribadi dan melakukan hubungan baik dengan orang lain, yang semuanya itu di dasarkan kepada keimanan dan ketaqwaan kepada Allah SWT, hal inilah yang menunjukkan adanya indikator dari peningkatan ESQ (Emotional-Spiritual Quotient) melalui ajaran tarekat Qodiriyah wa Naqsabandiyah tersebut. Upaya yang di lakukan pesantren ini dalam peningkatan kecerdasan emosional dan kecerdasan spiritual melalui ajaran tarekat Qodiriyah wa Naqsabandiyah terhadap para penganutnya antara lain:

a. Peningkatan ESQ melalui pengamalan dzikir yang di lakukan istiqomah.

b. Peningkatan ESQ melalui pencapaian tingkatan maqom lathifah sabjah.

c. Peningkatan ESQ melalui pengajaranya dalam menumbuhkan sifat takhalli, tahalli, dan tajalli.

d. Peningkatan ESQ (Emotional-Spiritual Quotient) melalui ritul keagamaan seperti istighotzah, khususiyah, manaqib Syaikh Abdul Qodir Jailani dan kegiatan-kegiatan sosial-keagamaan yang lainnya.

\section{UCAPAN TERIMA KASIH}

Ucapan terima kasih yang sangat besar penulis sampaikan kepada semua pihak yang telah sudi membantu penulisan artikel ini. Kritik dan saran, tidak bosan-bosannya penulis harapkan dari semua pihak agar selalu mendapatkan karya yang berkualitas.

Untaian terima kasih penulis haturkan sekali lagi dengan sedalam-dalamnya kepada kedua orang tua, keluarga, anak tercinta Muhammad Hasby Raivan Yusuf dan istri Asna Andriani yang telah memberikan kesempatan dalam penulisan artikel ini. Seluruh dewan Masayikh dan Mursyid tarekat Qodiriyah wa Naqsabandiyah Pondok Pesantren Miftahul Huda Malang, yang telah memberikan bimbingan baik dhohir maupun batin serta telah memberikan izin dan merestui penulisan artikel ini.

\section{DAFTAR PUSTAKA}

Al Qur'an, Al Qur'an Terjemah. 1978. Jakarta: DEPAG RI.

Agustian, Ary Ginanjar. 2001. Rahasia sukses Membangun ESQ (Emotional-Spiritual Quotient) berdasarkan 6 Rukun Iman dan 5 Rukun Islam. Jakarta: Arga.

As Sanjari, Abdur Rahman. 2001. Adakah Keraguan Terhadap Allah. Jakarta: Islami.

Aceh, Abu Bakar. 1992. Pengantar Ilmu Thariqah, Kajian Teoritik Tentang Mistik. Solo: CV. Rahmadhani.

Bruinessen, Martin Van. 1992. Tarekat Naqsabandiyah di Indonesia. Bandung: Mizan.

Bogdan, Robert C., dan Sari Knopp Biklen. 1998. Qualitative Research for Education: An Introduction to Theory and Methods. Boston: Aliyn and Bacon.

Budiman, Hikmat. 1996. Pembunuhan yang Selalu Gagal, Yokyakarta: Pustaka Pelajar.

Dahlan, Ahmad Zaini. 2011. “Tarekat Qadiriyah wa Naqsabandiyah dalam Dakwah Islamiyah (Kontribusi TGH. L. M. Turmuzi Badaruddin dalam Dakwah Islmiyah di Lombok Tengah Nusa Tenggara Barat)". Tesis. Program Pascasarjana UIN Maliki Malang.

Furchan, Arief. 1992. Pengantar Metode Kualitatif. Surabaya: Usaha Nasional.

Goleman, Daniel. 2003. Kecerdasan Emosi untuk mencapai Puncak Prestasi. Jakarta: PT. Gramedia Pustaka Utama.

Miles, Matthew B., dan Hubberman, A. Michael. 1992. Analisis Data Kualitatif, ter. Tjetjep Rohendi Rohidi. Jakarta: UI Press.

Moelong, Lexy J. 1999. Metodologi Penelitian Kualitatif. Tunggangri: PT Remaja Rosdakarya.

Sariyah. 2002. "Tarekat Aliran Qadiriyah Wa Naqsabandiyah di Suryalaya Tasikrnalaya Jawa Barat". Dalam Direktori Kusus-Kasus Aliran, Pemikiran, Paham, dan Gerakan Keagamaan di Indonesia. Jakarta: Puslitbang Kehidupan Keagamaan Kementerian Agama RI

Shapiro, Laurence E. 1999. Mengajarkan Emotional Intelegence pada Anak. Jakarta: PT. Gramedia Pustaka Utama. 
Shomad, Idris Abdul. 2005. Mengasah SQ dengan Dzikir. Jakarta: Pustaka Ikadi.

Sugiyono. 2013. Metode Penelitian Kuantitatif, Kualitatif dan Kombinasi (Mixed Methods). Bandung: ALFABETA.

Sujarwo, Eli. 2010. "pelaksanaan dakwah tarekat Qodiriyah wa Naqsabandiyah dalam pembinaan keagamaan santri Pondok Pesantren Darul Ulum Rejoso Petorangan
Jombang”. Skripsi. UIN Sunan Kalijaga Yogyakarta.

Tebba, Sudirman. 2003. Tasawuf Positif. Jakarta: Prenada Media.

Thohir, Ajid. 2002. Gerakan Politik Kaum Tarekat: Telaah Historis Gerakan Politik Antikolonialisme Tarekat Qodiriyah Naqsabandiyah di Pulau Jawa. Bandung: Pustaka Hidayah. 